\title{
KAJIAN POTENSI LIKUIFAKSI PASCA GEMPA DALAM RANGKA MITIGASI BENCANA DI PADANG
}

\author{
Hendri Warman ${ }^{1}$ dan Dwifitra Y Jumas ${ }^{2}$
}

\begin{abstract}
ABSTRAK
Pada tanggal 30 September 2009 pukul 17:16:09 Wib, sebuah gempa tektonik di lepas pantai Padang, Sumatera, dengan 7,6 Scala Richter (SR) terdaftar (United States Geological Survey, USGS, 2009). Pusat gempa terletak sekitar $71 \mathrm{~km}$ di bawah permukaan bumi dan sekitar $60 \mathrm{~km}$ Barat dari kota Padang. Hara (2009) diperkirakan berdasarkan tinggi frekuensi radiasi dan perpindahan maksimum amplitudes, bahwa durasi gempa 15,4 detik. Daerah yang paling terkena dampak adalah Kota Padang, Kota Pariaman, Kabupaten Padang Pariaman, Kabupaten Agam, dan Pesisir Selatan. Untuk kota Padang khususnya banyak bangunan dan perumahan yang roboh dan sarana jalan yang rusak (rengkah), hipotesis sementara telah terjadi peristiwa likuifaksi. Peristiwa likuifaksi merupakan kehilangan kekuatan tanah akibat terjadinya getaran didalam tanah, dimana terjadi peningkatan tekanan air pori. Penelitian ini dilakukan dengan tujuan untuk menelusuri kembali potensi likuifaksi di kota Padang akibat gempa 30 September 2009. Dalam penelitian ini di dilakukan kajian untuk 3(tiga) lokasi yang dapat mewakili kota Padang yaitu daerah Air Pacah untuk wilayah Timur, daerah Siteba untuk tengah dan daerah Purus untuk wilayah Barat. Penyelidikan tanah dengan menggunakan alat Bor Tangan (hand bor) dan CPT (sondir) hingga kedalaman tanah keras. Selanjutnya diteruskan uji laboratorium untuk melihat susunan butiran tanah pada kedalaman tertentu dan dianalisis dengan cara membandingkan kurva gradasi dengan kurva potensi likuifaksi. Dari hasil kajian penelitian yang telah dilakukan, menunjukan bahwa daerah Purus (Raden Saleh), Siteba, daerah By Pass memiliki nilai faktor keamanan kecil $(<0,5)$ dibandingkan dengan faktor keamanan yang ditetapkan, yaitu 1,5. Hasil penelusuran potensi likuifaksi untuk ketiga lokasi daerah Padang memberikan informasi memiliki potensi likuifaksi.
\end{abstract}

Kata kunci : Likuifaksi, gempa bumi, tekanan air pori.

\section{PENDAHULUAN}

\subsection{Latar Belakang}

Kota Padang merupakan salah satu kota yang berpotensi besar mengalami getaran tanah akibat gempa dan mempunyai berpotensi untuk terjadinya Likuifaksi. Peristiwa likuifaksi adalah perilaku tanah di bawah beban siklik yang terjadi hanya dalam beberapa saat. Akibat beban siklik yang singkat tersebut, massa tanah tiba-tiba mengalami transisi dari keadaan padat ke keadaan cair atau memiliki konsistensi utama seperti cairan. Peristiwa likuifaksi saat gempa dapat ditandai dengan adanya pergerakan tanah dalam arah horizontal, rembesan air keluar dari rekahan tanah, bergeraknya bangunan miring atau turun, penurunan muka tanah, serta terjadinya longsor pada

\footnotetext{
${ }^{I}$ Staf Pengajar Jurusan Teknik Sipil Fakultas Teknik Sipil dan Perencanaan Universitas Bung Hatta, e-mail: warman_hendri@yahoo.com

${ }^{2}$ Staf Pengajar Jurusan Quantity Surveying Fakultas Teknik Sipil dan Perencanaan Univ. Bung Hatta, e-mail: dwifitraj@yahoo.com
} 
tanggul dan lereng. Pada bangunan yang berada pada daerah terlikuifaksi dapat berakibat terjadinya amblas, miring atau bergerak ke samping atau bahkan mengakibatkan keruntuhan bangunan tersebut.

Pada tahun 1964 gempa bumi di Niigata serta gempa bumi di Alaska telah dilaporkan membuat sejumlah bangunan bangunan terguling dan miring. Fenomena kasus Niigata telah menarik banyak perhatian dari insinyur dan ahli gempa di dunia. Peristiwa likuifaksi yang pada areal yang luar biasa luasnya mengakibatkan sejumlah bangunan apartemen dekat tepian sungai mengalami kegagalan daya dukung dan miring sebegitu parahnya seperti yang ditunjukkan pada Gambar 1.1 (Wikipedia, 2009). Meskipun bangunan itu mengalami kemiringan yang sangat ekstrim, bangunan itu sendiri tidak menderita kerusakan berarti secara struktural. Sejumlah studi untuk mengevaluasi potensi likuifaksi dalam deposit tanah telah dilakukan di masa lalu. Kebanyakan dari mereka studi didasarkan pada uji lapangan geoteknik. Seed \& Idriss (1982) telah melakukan studi komprehensif tentang likuifaksi tanah. Analisis likuifaksi dapat didasarkan pada parameter tanah dari laboratorium serta uji lapangan.

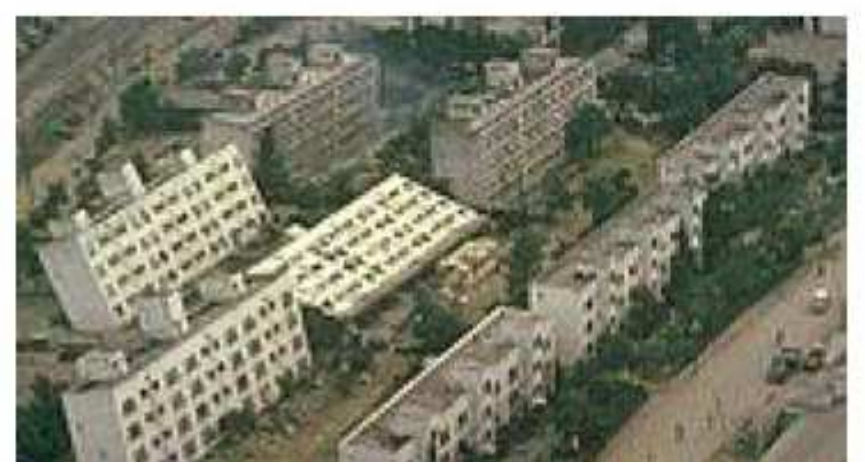

Gambar 1.1 Peristiwa likuifaksi Niigata 1964

Metoda untuk mendapatkan potensi likuifaksi yang telah ada, salah satunya adalah metoda analisa dengan menggunakan pengujian lapangan, seperti uji sondir (CPT), uji standar penetrasi, uji boring dan uji Swedish. Sedangkan metoda uji laboratorium yaitu analisa butiran. Uji sondir dilapangan dan uji analisa saringan di laboratorium, merupakan yang sering dilakukan karena relatif lebih mudah dan ekonomis dalam pelaksanaannya.

\subsection{Permasalahan}

Kondisi geografis Kota Padang terletak pada daerah dataran dan sebagian terbentang disekitar pantai mulai dari selatan sampai ke utara, sedangkan bagian barat langsung berhadapan dengan lautan Hindia dan bagian Timur sudah berbatasan langsung dengan daerah perbukitan. Bencana alam khususnya gempa bumi ataupun gempa tektonik sudah merupakan bagian dari kondisi yang tidak bisa terelakkan, sehingga perlu kiranya dilakukan upaya-upaya pengurangan risiko bencana. Kota Padang merupakan daerah pemukiman padat penduduk khususnya bagian Barat dan perencanaan bangunan maka diperlukan pengetahuan tentang kondisi lapisan tanah, sehingga dalam pembangunan perumahan /pemukiman ataupun gedung akan dapat meminimalisir bencana yang timbul. Bahaya terjadinya likuifaksi pada pasca gempa bumi tahun 2009 dapat dilihat dengan terjadinya amblas bangunan, rengkah/terbelahnya bangunan atau ditandai dengan keluarnya air dari dalam tanah saat terjadinya gempa bumi, kondisi ini sangatlah membahayakan keselamatan masyarakat. 
Untuk itu perlu dilakukan penelusuran potensi likuifaksi yang telah terjadi di kota Padang, sehingga apabila dilakukan pembangunan struktur atau penataan pemukiman, maka dapat dilakukan perencanaan yang ramah gempa. Penataan ruang/pemukiman kembali dapat dijadikan cara untuk tindakan mitigasi atau meminimalisir bencana di wilayah kota Padang.

\subsection{Tujuan}

Penelitian ini difokuskan untuk membuktikan secara empiris hipotesis di atas untuk kondisi kegempaan kawasan Kota Padang akibat likuifaksi. Bentuk pembuktian akan diwujudkan dalam pengembangan metode prediksi kerusakan pada bangunan, sedang hal yang digunakan sebagai alat bantu pembuktian adalah hasil uji sondir. Dalam proses pembuktian akan didapatkan luaran sebagai berikut:

1. Sistem informasi kondisi tanah dan bahaya likuifaksi di Kota Padang dengan mendapatkan angka keamanan terhadap bahaya potensi likuifaksi.

2. Peta potensi prediksi kerusakan akibat likuifaksi

\subsection{Batasan Masalah}

Dalam penelitian ini, batasan pembahasan adalah :

1. Analisa potensi likuifaksi hanya untuk beberapa titik saja untuk daerah By Pass, dan Purus (Raden Saleh)

2. Metoda yang dilakukan adalah uji sondir dilapangan dan uji saringan di laboratorium.

\section{TINJAUAN PUSTAKA}

\subsection{Umum}

Peristiwa likuifaksi adalah perilaku tanah di bawah beban siklik yang terjadi akibat beban siklik yang singkat, massa tanah tiba-tiba mengalami transisi dari keadaan padat ke keadaan cair atau memiliki konsistensi utama seperti cairan. Peristiwa likuifaksi saat gempa dapat ditandai dengan adanya pergerakan tanah dalam arah horizontal, rembesan air keluar dari rekahan tanah, bergeraknya bangunan miring atau turun, penurunan muka tanah, serta terjadinya longsor pada tanggul dan lereng. Pada bangunan yang berada pada daerah terlikuifaksi dapat berakibat terjadinya amblas, miring atau bergerak ke samping atau bahkan mengakibatkan keruntuhan bangunan tersebut. Dari sejumlah catatan kejadian yang telah lalu, diketahui bahwa peristiwa likuifaksi lebih berpotensi terjadi pada konsistensi tanah granular jenuh yang lepas dengan sifat drainase didalam tanah yang jelek. Deposit tanah yang berpotensi terlikuifaksi pada saat terjadinya gempa adalah pasir halus, pasir berlumpur dan pasir biasa. Apabila beban siklik terjadi seperti saat gempa bumi, pasir lepas cenderung pengalami penurunan volume, hal ini mengakibatkan terjadinya peningkatan tekanan air pori dan penurunan kekuatan geser effektif tanah. Pada saat itu pula tegangan dalam elemen tanah meningkat. Untuk waktu yang singkat, peningkatan tegangan dalam elemen tanah terjadi dalam bentuk tekanan pori, sedangkan tegangan efektif antara partikel tanah relatif tetap. Peningkatan tegangan sesaat ini, pada deposit berpasir yang sangat permeabel, akan ditransfer langsung ke tegangan efektif antara partikel. Namun untuk tanah berpasir yang semi-permeable, seperti pasir berlumpur dan pasir halus, waktu terjadinya peningkatan tekanan pori sangat pendek dibandingkan dengan waktu yang dibutuhkan untuk mentransfer kedalam bentuk tegangan effektif partikel-partikel tanah. Jika peningkatan tekanan pori lebih besat dibandingkan tegangan efektif butiran tanah, maka tanah akan berperilaku sebagai mana cairan. Dalam persamaan matematika, likuifaksi pada deposit tanah ditulis sebagai: 


$$
\sigma^{\prime}=\sigma-\mathrm{u}<0.0 \text { atau, } \sigma^{\prime}<\Delta \mathrm{u}
$$

Dimana $\sigma$ dan $\sigma^{\prime}$ adalah tegangan total dan efektif di dalam tanah, u adalah tekanan pori dalam elemen tanah dan $\Delta \mathrm{u}$ adalah peningkatan tegangan pori akibat getaran.

\subsection{Evaluasi Potensi Likuifaksi}

Potensi likuifaksi pada suatu deposit tanah akan ditentukan oleh kombinasi beberapa komponen, antara lain :

a. Nilai Indeks properties tanah, seperti modulus dinamis, karakteristik kelembaban, berat isi, gradasi butiran, kepadatan relatif dan struktur tanah itu sendiri.

b. Faktor lingkungan, seperti jenis formasi tanah, sejarah seismik dan geologi, posisi muka air tanah dan tegangan efektif tanah.

c. Karakteristik gempa, seperti intensitas guncangan pada tanah dan lama getaran .

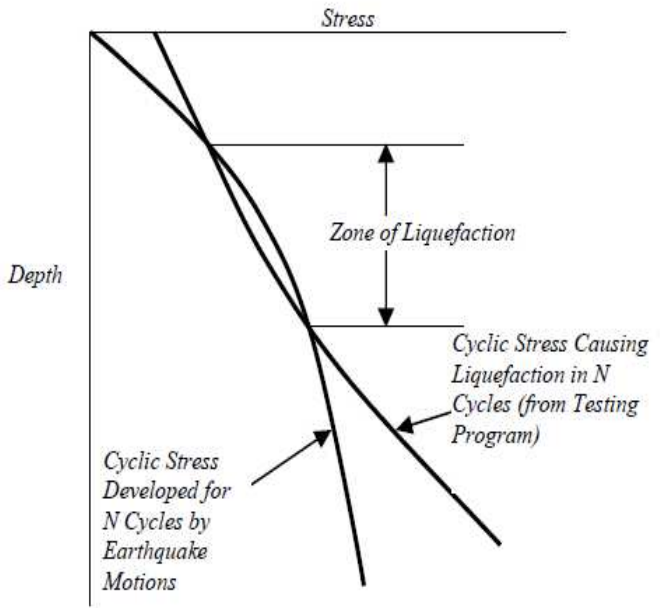

Gambar 2.1 Metode Evaluasi Potensi Likuifaksi Tanah (Ground Motion and Soil Liquefaction During Earthquakes, Seed \& Idriss, 1982)

Dari beberapa faktor yang telah disebutkan di atas, tidak semua dari faktor tersebut dapat ditentukan besarannya secara langsung, akan tetapi dampak yang muncul dari ketiga faktor tersebut dapat digunakan atau dimasukkan kedalam prosedur evaluasi potensial likuifaksi, yaitu dengan melakukan uji beban siklik pada sampel tanah tak terganggu atau bisa juga dengan cara pengukuran karakteristik likuifaksi pada tanah menggunakan beberapa prosedur pengujian di lapangan. Pada dasarnya, prosedur standar evaluasi likuifaksi, antara lain:

a. Menentukan besaran tegangan siklik yang muncul akibat pergerakan tanah pada saat gempa bumi, pada setiap kedalaman deposit tanah dan mengkonversi bentuk tegangan yang tidak beraturan tersebut hingga memiliki besaran yang sama dalam bentuk tegangan siklik. Dengan kata lain, intensitas guncangan, lama guncangan dan variasi guncangan yang terjadi akibat tegangan pada setiap kedalaman diubah menjadi suatu besaran yang dapat dihitung. Penentuan besaran tegangan siklik yang terjadi dapat dilakukan dengan cara menganalisa respon tanah terhadap tegangan yang terjadi dengan melibatkan berat sendiri tanah, modulus dinamik dan karakteristik kelembaban.

b. Menentukan besaran tegangan siklik dengan cara uji pembebanan di laboratorium yang diwakili oleh sampel tak terganggu yang dilakukan dengan variasi tekanan bebas yang telah ditentukan atau dengan cara mengkorelasikan properties tanah dengan karakteristik tanah di lapangan.

\section{4 | JURNAL REKAYASA SIPIL}


c. Membandingkan antara tegangan geser yang terjadi akibat gempa bumi dengan hal-hal yang dapat menyebabkan terjadinya likuifaksi untuk menentukan apakah deposit tanah berada dalam zona likuifaksi atau tidak, seperti yang ditunjukkan oleh gambar 2.1.

Perilaku likuifaksi pada tanah bersifat merusak dan menimbulkan dampak negatif yang besar terhadap stabilitas tanah dan bangunan diatasnya. Adapun dampak yang ditimbulkan dari perilaku likuifaksi adalah :

1. Terjadinya penurunan tanah hingga $5 \%$ ketebalan lapisan tanah terlikuifaksi.

2. Terjadinya kehilangan daya dukung lateral tanah.

3. Terjadinya kehilangan daya dukung tanah.

4. Terjadinya pengapungan struktur yang dibenamkan dalam tanah, seperti tanki di bawah tanah.

5. Meningkatkan tekanan lateral tanah yang dapat menyebabkan kegagalan pada struktur penahan tekanan lateral tanah, seperti quay walls.

6. Terjadinya lateral spreading (limited lateral movements).

7. Terjadinya lateral flow (extensive lateral movements).

\subsection{Parameter Likuifaksi}

Parameter likuifaksi merupakan parameter yang digunakan sebagai dasar dalam menentukan kriteria likuifaksi yang terjadi pada deposit tanah. Dimana dalam hal ini, perilaku likuifaksi pada tanah dipengaruhi oleh dua parameter utama, yaitu perlawanan terkoreksi $\left(\mathrm{q}_{\mathrm{cl}}\right)$ dan rasio tegangan siklik (CSR). Normalisasi perlawana konus perlu dilakukan karena pada dasarnya nilai $\mathrm{q}_{\mathrm{c}}$ yang diperoleh dari uji sondir yang dilakukan untuk mengkoreksi nilai $\mathrm{q}_{\mathrm{c}}$ yang didapatkan berdasarkan besarnya tegangan efektif overbuden tanah, $\sigma o^{\prime}$ (Seed et al. 1983) adalah sebagai berikut:

$$
q c_{1}=C_{1} x q_{c}=C_{N} x q_{c} \quad(\mathrm{~kg} / \mathrm{cm} 2)
$$

dimana :

$\mathrm{q}_{\mathrm{c} 1}=$ perlawanan konus tekoreksi $(\mathrm{kg} / \mathrm{cm} 2)$

$\mathrm{q}_{\mathrm{c}}=$ perlawanan konus $(\mathrm{kg} / \mathrm{cm} 2)$

$\mathrm{C}_{\mathrm{N}}=$ faktor koreksi (Grafik 2.1)

Cyclic Stress Ratio (CSR) merupakan sebuah variabel yang digunakan untuk mendefinisikan gejala kegempaan yang terjadi pada lapisan tanah. Dimana, dalam beberapa tahun terakhir variabel dimasukkan sebagai variabel perhitungan potensi likuifaksi pada tanah. Tokimatsu dan Yoshimi (1983) mengeluarkan persamaan untuk perhitungan CSR sebagai berikut:

$$
\operatorname{CSR}=0,1 \times(\mathrm{M}-1) \times \frac{a_{\max } \times \sigma_{0}}{\mathrm{~g} \times \sigma_{0}^{\prime}} \times(1-0,015 \times \mathrm{z})
$$

dimana:
бo adalah inisial dari tegangan vertical yang terjadi
$\sigma o^{\prime}$ adalah inisial terhadap tegangan vertical efektif
M adalah magnitudo gempa bumi
$\alpha_{\max } \quad$ adalah percepatan maksimum tanah
$\mathrm{z} \quad$ adalah kedalaman yang dinyatakan dalam meter $(\mathrm{z}<25 \mathrm{~m})$

Seed dan Idriss (1971) juga pernah merumuskan persamaan perhitungan nilai CSR tanah, yaitu: 


$$
\operatorname{CSR}=0,65 \times\left(\frac{a_{\max } \times \sigma_{0}}{g \times \sigma_{0}^{\prime}}\right) \times \mathbf{r}_{\mathrm{d}}
$$

dimana:

$$
\begin{array}{ll}
\alpha_{\mathrm{ma}} \mathrm{X} & =\text { percepatan tanah maksimum }(\mathrm{gal}) \\
\mathrm{g} & =\text { percepatan gravitasi }(\mathrm{mm} / \mathrm{s}) \\
\sigma o^{\prime} & =\text { tekanan efektif tanah }(\mathrm{kg} / \mathrm{cm} 2) \\
\sigma \mathrm{o} & =\text { tekanan total pada tanah }(\mathrm{kg} / \mathrm{cm} 2) \\
\mathrm{r}_{\mathrm{d}} & =\text { reduksi tegangan }
\end{array}
$$



Gambar 2.1 Grafik hubungan CN dan tegangan efektif tanah (Ground Motion and Soil Liquefaction During Earthquakes, Seed \& Idriss, 1982)

Dimana $r_{d}$ merupakan koefisien reduksi tegangan pada suatu kedalaman yang dirumuskan untuk mengestimasi besarnya koefisien reduksi besaran CSR. Beberapa ahli mengembangkan dan mengusulkan formulasi untuk mengestimasi koefisien reduksi tegangan, diantaranya:

\section{Liao and Whitman (1986)}

$$
\begin{aligned}
& \mathrm{r}_{\mathrm{d}}=1,0-0,00765 \mathrm{z} \text { for } \mathrm{z} \leq 9,15 \text { meters } \\
& \mathrm{r}_{\mathrm{d}}=1,174-0,00267 \mathrm{z} \text { for } 9,15 \text { meters }<\mathrm{z}<23 \text { meters }
\end{aligned}
$$

\section{Blake (1996)}

$$
r_{\mathrm{d}}=\frac{1,0-0,4113 z^{1,5}+0,04052 z+0,001753 z^{1,5}}{1,0-0,4177 z^{0,5}+0,05729 z-0,006205 z^{1,5}+0,00121 z^{2}}
$$

Selain parameter yang telah disebutkan, dalam melakukan analisa potensi likuifaksi dibutuhkan suatu variabel yang diintrepetasikan dalam sebuah persamaan yang dapat mendefinisikan kapasitas tanah sebagai tahanan likuifaksi. Para ahli menginisiasikan tahanan tanah terhadap likuifaksi dengan simbol CRR (Cyclic Resistance Ratio). Robertson dan Wride (1998) membuat sebuah rujukan dalam bentuk grafik hubungan CRR dengan Nilai qc1 terkoreksi pada pasir halus dengan

\section{6 | JURNAL REKAYASA SIPIL}


FC (Fine Contents) $\leq 5 \%$ dan grafik ini hanya berlaku untuk magnitude gempa yang terjadi sebesar 7,5 SR. Grafik hubungan antara CRR dan qc1 terkoreksi ditunjukkan oleh gambar 2.2. Grafik hubungan qc1 dan CRR atau CSR dari Robertson dan Wride (1998) ini didasarkan pada persamaan yang digunakan untuk memperkirakan nilai CRR pada tanah, yaitu :

$$
\begin{array}{ll}
\text { Jika, } \mathrm{q}_{\mathrm{c} 1}<50 & \mathrm{CRR}_{7,5}=0,833\left(\mathrm{q}_{\mathrm{cl}} / 1000\right)+0,05 \\
\text { Jika, 50< }<\mathrm{q}_{\mathrm{c} 1}<160 & \mathrm{CRR}_{7,5}=93\left(\mathrm{q}_{\mathrm{c} 1} / 1000\right) 3+0,08
\end{array}
$$

Nilai CRR tanah ini digunakan untuk menentukan faktor keamanan dari perilaku likuifaksi pada tanah, yaitu dengan cara membandingkan antara CSR dengan CRR :

$$
\mathrm{FSL}=\left(\frac{\mathrm{CSR}}{\mathrm{CRR}}\right)_{\mathrm{MSF}}
$$



Gambar 2.2 Hubungan qc dan CSR terhadap potensi likuifaksi (Robertson and Wride, 1998)

Dimana nilai MSF (Magnitude Scalling Factor) dihitung dengan menggunakan rumus Youd, et.al (2001) yaitu:

$$
\mathrm{MSF}=10^{2,24} / \mathrm{M}^{2,56}
$$

\section{METODOLOGI}

\subsection{Penyelidkan Lapangan}

Kegiatan penelitian dimulai dengan survey awal lapangan untuk mencari posisi titik penyelidikan tanah. Adapun daerah yang dilakukan untuk penelitian seperti Purus Atas di Jalan Raden Saleh, daerah Siteba dan daerah By Pass km 16. Penyelidikan Tanah di Lapangan.dengan melakukan pekerjaan penyondiran dan pengeboran tanah untuk mendapatkan kedalaman tanah dan sampel. 
1. Penyelidikan tanah di lapangan dengan melakukan teknik penyondiran tanah untuk 3 (dua) titik lokasi Purus Atas

2. Penyelidikan tanah di lapangan dengan melakukan teknik penyondiran tanah untuk 3 (tiga) titik lokasi.di Siteba, dan

3. Penyelidikan tanah di lapangan dengan melakukan teknik penyondiran tanah untuk 2 (dua) titik lokasi.di jl. By Pass

Metode Sondir ( ASTM D 3441-86 )

Hasil dari penyelidikan ini akan menghasilkan nilai-nilai sebagai berikut :

1. ( NK ) : Perlawanan konus/conus resistance $(\mathrm{kg} / \mathrm{cm} 2)$

2. ( JHP ) : Jumlah hambatan pelekat/total friction resistance $(\mathrm{kg} / \mathrm{cm} 2)$

Pengamatan serta pencatatan nilai perlawanan konus (NK) dan jumlah hambatan pelekat (JHP) dlakukan setiap interval $20 \mathrm{~cm}$ dengan kedalaman maksimum $20 \mathrm{~m}$ atau dihentikan sampai pada tekanan konus telah mencapai besar dari $150 \mathrm{~kg} / \mathrm{cm} 2$. Hasil dari pembacaan penyondiran ini akan ditampilkan dalam bentuk grafik hubungan antara nilai perlawanan konus (NK) dan jumlah hambatan pelekat (JHP) dengan kedalaman tanah yang dikerjakan.

\subsection{Penyelidkan Laboratorium}

Pengujian di laboratorium ini dimaksudkan untuk mengetahui sifat-sifat fisik dan struktur, dimana sampel tanah yang diambil dari 3(tiga) lokasi penelitian diuji. Standar yang dipakai untuk pengujian contoh sirtu ini di laboratorium ada pada tabel 3.1 dibawah ini :

Tabel 3.1 Uji Laboratorium

\begin{tabular}{|l|l|l|}
\hline No. & Jenis Pengujian & Standar Pemeriksaan \\
\hline 1 & Analisa Saringan (Sieve Analysis) & ASTM D.422-72 \\
\hline 2 & Kadar Air Tanah & ASTM D.2216-71 \\
\hline 3 & Berat Jenis Tanah (Specific Gravity) & ASTM D.854 - 58 \\
\hline 4 & Atterberg Limits & ASTM D.423, ASTM D.424 \\
\hline 5 & Direct Shear Test & ASTM D.3080-72 \\
\hline
\end{tabular}

Tabel 3.2 Nilai estimasi berat volume tanah (Robertson et al, 1986)

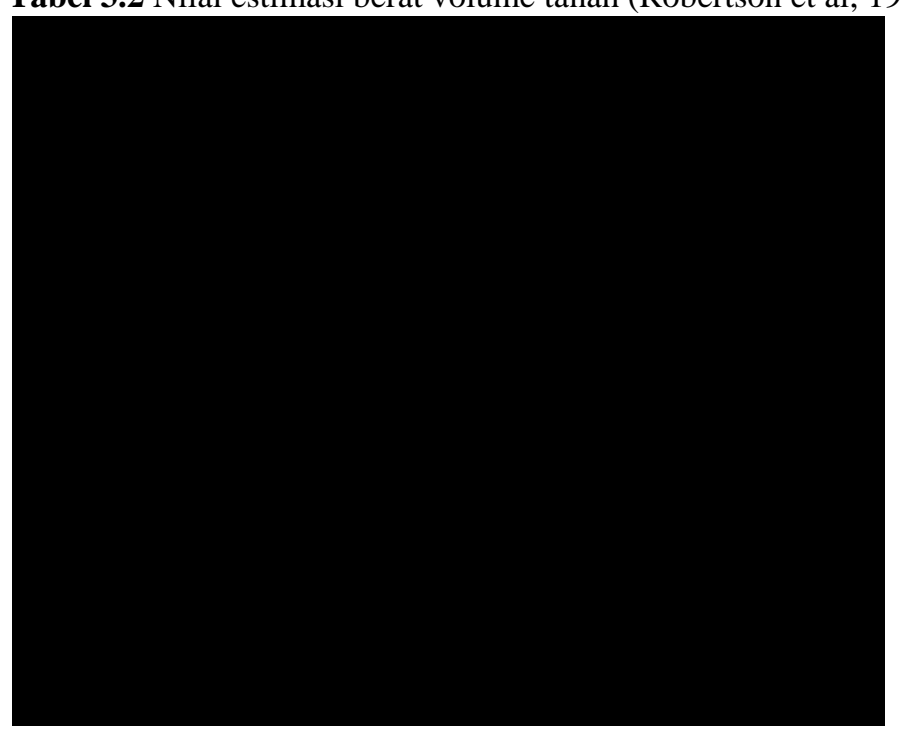




\subsection{Perhitungan Potensi Likuifaksi}

\subsubsection{Menentukan Jumlah Lapisan dan Penomoran Lapisan}

Jumlah dan penomoran lapisan ditentukan berdasarkan bentang kedalaman tertentu, yang bertujuan untuk mempermudah dalam melakukan analisa dan perhitungan. Dalam laporan ini, perhitungan dilakukan untuk setiap lapisan dengan rentang data 1 meter kedalaman .

\subsubsection{Estimasi berat volume tanah}

Estimasi berat volume tanah dapat ditentukan berdasarkan jenis tanah dengan melihat tabel 3.2.

\subsubsection{Menentukan magnitude dan percepatan tanah maksimum (amax)}

Magnitude gempa dan percepatan tanah maksimum digunakan dalam perhitungan cyclic stress ratio. Parameter ini diperoleh dari data gempa Padang Pariaman pada tanggal 30 September 2009 yaitu magnitude 7,6SR dan amax sebesar 0,28 g berdasarkan gambar 3.1.dalam perhitungan, percepatan tanah digunakan dalam satuan Gal.

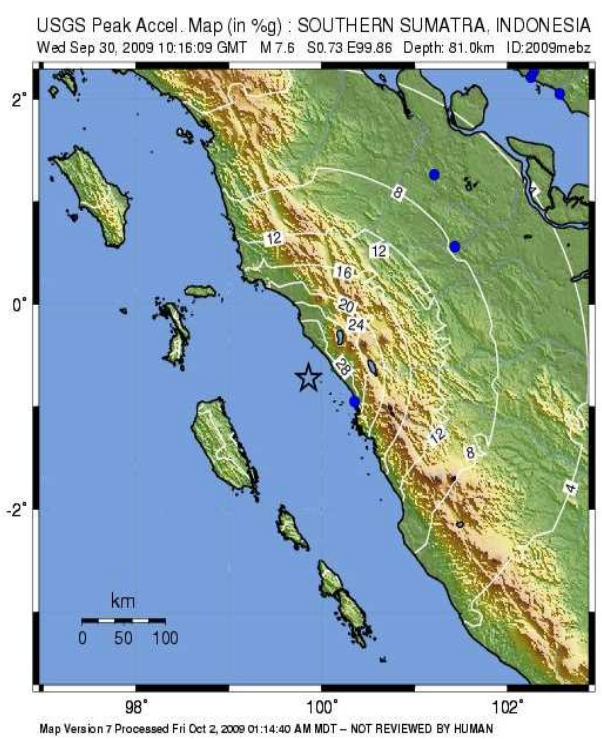

Gambar 3.1 Data percepatan tanah gempa 30 September 2009

\subsection{CPT (Cone Penetration Test)}

\subsubsection{Menghitung nilai Cyclic Stress Ratio (CSR)}

Besarnya nilai Cyclic Stress Ratio ditentukan berdasarkan persamaan dari Seed \& Idriss (1971):

$$
\operatorname{CSR}=0,65 \times\left(\frac{a_{\max } \times \sigma_{0}}{g \times \sigma_{0}{ }^{\circ}}\right) \times \mathbf{r}_{\mathrm{d}}
$$

dimana:

$\sigma_{0}^{\prime} \quad=$ Tekanan efektif tanah $(\mathrm{kg} / \mathrm{m} 2)$

$\sigma_{0} \quad=$ Tekanan total pada tanah $(\mathrm{kg} / \mathrm{m} 2)$

$\mathrm{g} \quad=$ percepatan gravitasi $(\mathrm{cm} / \mathrm{dtk} 2)$ 


\subsubsection{Menentukan tegangan total}

Tegangan total pada tanah dihitung menggunakan persamaan dari Seed \& Idris (1971).

$$
\sigma_{0}=h \cdot \gamma
$$

dimana:

$$
\begin{array}{ll}
\sigma_{0} & =\text { Tegangan total }(\mathrm{kg} / \mathrm{m} 2) \\
\mathrm{h} & =\text { Kedalaman }(\mathrm{m}) \\
\gamma & =\text { Berat volume }(\mathrm{kg} / \mathrm{m} 3)
\end{array}
$$

\subsubsection{Menentukan tegangan efektif}

Tegangan efektif pada tanah dihitung menggunakan persamaaan dari Seed \& Idriss (1971);

$$
\sigma_{0}^{\prime}=\sigma_{0}-u=(\mathrm{h} \times \gamma)-\left(\mathrm{h}_{\mathrm{w}} \times \gamma_{\mathrm{w}}\right)
$$

dimana:

$$
\begin{array}{ll}
\sigma_{0}, & =\text { Tekanan efektif tanah }\left(\mathrm{kg} / \mathrm{m}^{2}\right) \\
\sigma_{0} & =\text { Tekanan total pada tanah }\left(\mathrm{kg} / \mathrm{m}^{2}\right) \\
u & =\text { Tekanan air pori }\left(\mathrm{kg} / \mathrm{m}^{2}\right) \\
\mathrm{h} & =\text { Kedalaman }(\mathrm{m}) \\
\gamma & =\text { Berat volume tanah }\left(\mathrm{kg} / \mathrm{m}^{3}\right) \\
\mathrm{h}_{\mathrm{w}} & =\text { Kedalaman muka air tanah }(\mathrm{m}) \\
\gamma_{\mathrm{w}} & =\text { Berat volume air }\left(\mathrm{kg} / \mathrm{m}^{3}\right)
\end{array}
$$

\subsubsection{Menentukan faktor reduksi tegangan $\left(r_{d}\right)$}

Faktor reduksi tegangan dihitung berdasarkan persamaan Blake tahun 1996:

$$
r_{d}=\frac{1,0-0,4113 z^{1,5}+0,04052 z+0,001753 z^{1,5}}{1,0-0,4177 z^{0,5}+0,05729 z-0,006205 z^{1.5}+0,00121 z^{2}}
$$

Dimana $\mathrm{z}$ merupakan nomor lapisan dan $\mathrm{r}_{\mathrm{d}}$ merupakan sebuah koefisien reduksi tegangan yang terjadi di setiap kedalaman yang ditinjau.

\subsubsection{Menentukan perlawanan konus terkoreksi $\left(q_{\mathrm{c} 1}\right)$}

Perlawanan konus terkoreksi dihitung berasarkan persamaan yang dikeluarkan oleh Seed \& Idriss (1982);

$$
\mathrm{q}_{\mathrm{c} 1}=\mathrm{C}_{\mathrm{N}} \cdot \mathrm{q}_{\mathrm{c}}
$$

dimana:

$$
\begin{array}{ll}
\mathrm{q}_{\mathrm{c} 1} & =\text { Perlawanan konus terkoreksi }\left(\mathrm{kg} / \mathrm{m}^{2}\right) \\
\mathrm{C}_{\mathrm{N}} & =\text { Perlawanan konus }\left(\mathrm{kg} / \mathrm{m}^{2}\right) \\
\mathrm{q}_{\mathrm{c}} & =\text { Koreksi perlawanan konus }
\end{array}
$$

Dari nilai $C_{N}$ berdasarkan gambar 2.1 diatas, yaitu hubungan antara tegangan efektif dan $C_{N}$. 


\subsubsection{Menentukan potensi likuifaksi berdasarkan hubungan CSR dan perlawanan konus terkoreksi}

Seed \& Idriss (1971) menentukan potensi likuifaksi berdasarkan grafik pada gambar 3.1 dan gambar 3.2. Pemilihan grafik didasari dari nilai $\mathrm{D}_{50}$ berdasarkan dari data skunder yang ada. Grafik merupakan hubungan antara CSR dan perlawanan konus terkoreksi.

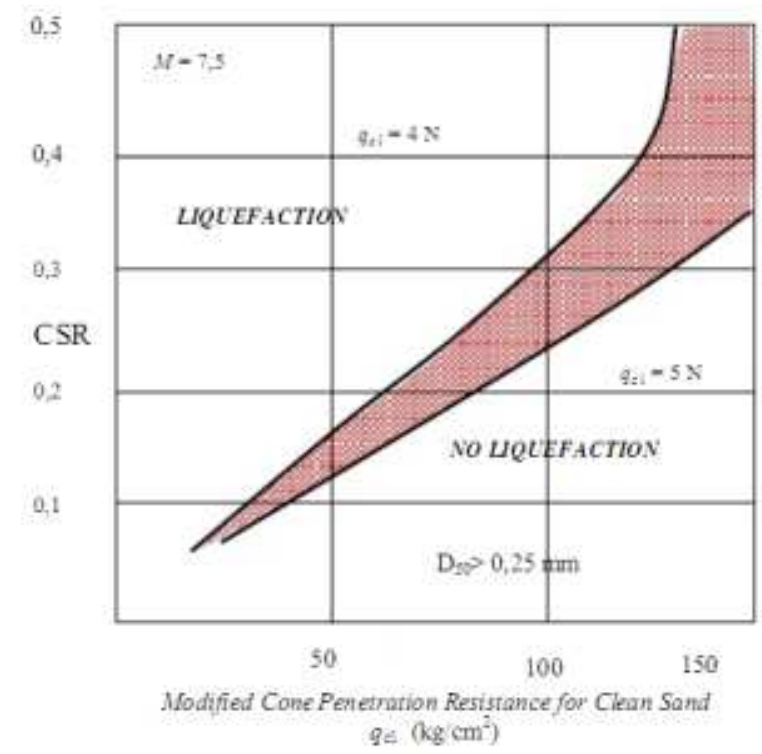

Gambar 3.1 Grafik CSR vs perlawanan konus terkoreksi uji sondir untuk tanah pasir (Ground Motion and soil liquefaction during earthquakes, Seed \& Idriss, 1982)

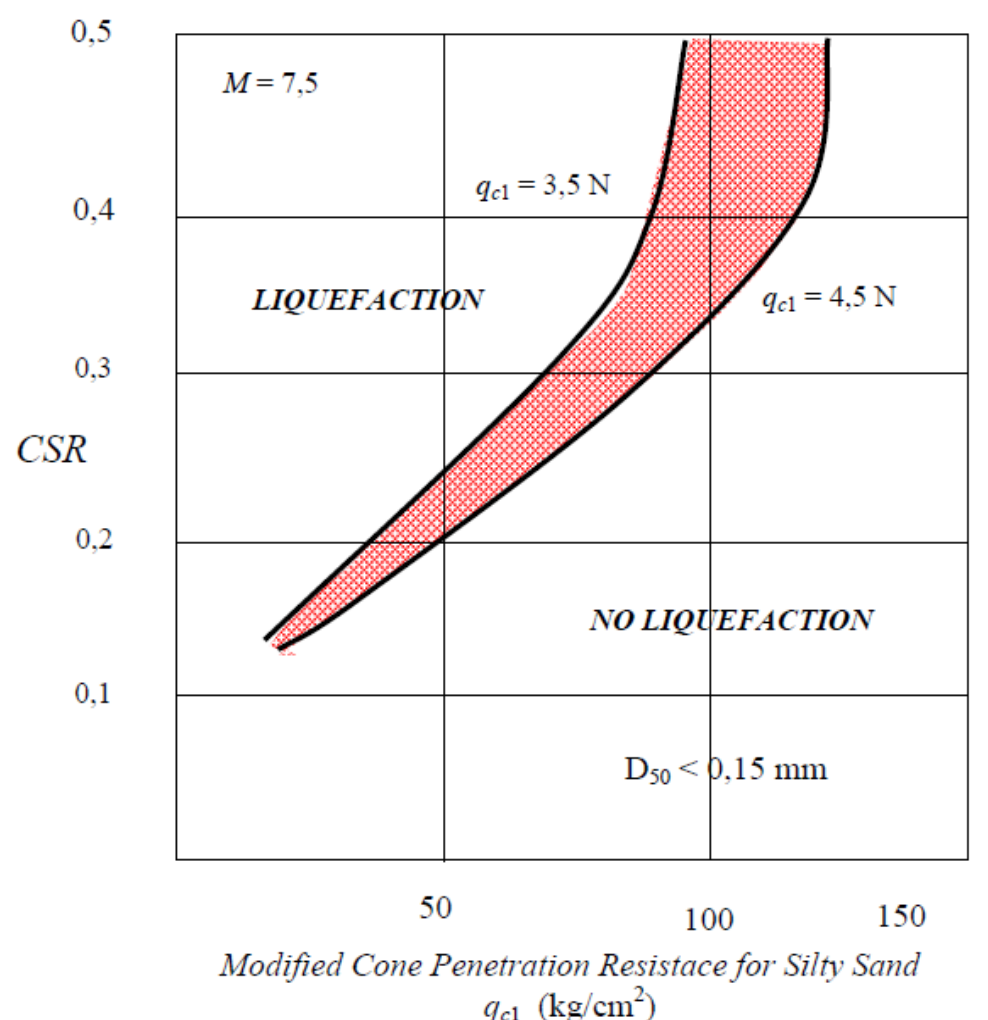

Gambar 3.2 Grafik CSR vs perlawanan konus terkoreksi uji sondir untuk tanah pasir berlempung (Ground Motion and soil liquefaction during earthquakes, Seed \& Idriss, 1982) 


\subsubsection{Menghitung nilai Cyclic Resistant Ratio (CRR)}

Besarnya nilai CRR dapat dihitung dengan menggunakan persamaan di bawah ini:

$$
\begin{array}{lr}
\text { Jika, } q_{c 1}<50 & C R R_{7,5}=0,833\left(q_{c 1} / 1000\right)+0,05 \\
\text { Jika, 50 }<q_{c 1}<160 & C R R_{7,5}=93\left(q_{c 1} / 1000\right)^{3}+0,08
\end{array}
$$

\section{HASIL PENELITIAN}

\subsection{CPT (Cone Penetration Test)}

Dari penyelidikan tanah di lapangan diperoleh data lapangan sebagai berikut:

\subsubsection{Lokasi dan titik pengujian sondir}

Dalam penelitian ini, melakukan pengambilan data lapangan untuk perhitungan potensi likuifaksi dilakukan pada lokasi jl. Raden Saleh Padang. Pada daerah ini dilakukan pengambilan data uji sondir sebanyak 3 titik sampai kedalaman 4,0 meter.

\subsubsection{Data sondir lapangan}

Dari data diperoleh nilai perlawanan konus $\left(\mathrm{q}_{\mathrm{c}}\right)$ dan rasio gesekan $\left(\mathrm{R}_{\mathrm{f}}\right)$. Data uji sondir ditampilkan setiap 0,2 m kedalaman. Selanjutnyadilakukan penomoran berdasarkan rentang kedalaman tertentu yang diikuti dengan penentuan nilai perlawanan konus rata-rata $\left(\mathrm{q}_{\mathrm{c}}\right)$ dan rasio gesekan $\left(\mathrm{R}_{\mathrm{f}}\right)$ rata-rata. Dimana, data ini diperlukan untuk menghitung nilai normalisasi tahanan kerucut $\left(\mathrm{q}_{\mathrm{c} 1}\right)$. Data hasil pengujian sondir dapat dilihat pada Tabel 4.1

\subsubsection{Kedalaman tanah keras}

Kedalaman tanah keras ditemukan hingga kedalaman 3,0 m.

Tabel 4.1 Nilai $\mathrm{q}_{\mathrm{c}}$ dan $\mathrm{R}_{\mathrm{f}}$

\begin{tabular}{|c|c|c|c|c|}
\hline Titik & $\begin{array}{c}\text { Layer } \\
\text { Number }\end{array}$ & $\begin{array}{c}\text { Depth } \\
\text { range }(\mathrm{m})\end{array}$ & $\begin{array}{c}\text { Depth } \\
(\mathrm{cm})\end{array}$ & $\begin{array}{c}\mathrm{qc} \\
(\mathrm{kg} / \mathrm{cm} 2)\end{array}$ \\
\hline \multirow{3}{*}{1} & 1 & $0-1$ & 100 & 6 \\
\cline { 2 - 5 } & 2 & $1,2-2$ & 200 & 22 \\
\cline { 2 - 5 } & 3 & $2,2-3$ & 300 & 32 \\
\cline { 2 - 5 } & 4 & $3,2-4$ & 400 & 90 \\
\hline
\end{tabular}

\subsubsection{Muka air tanah}

Muka Air Tanah (MAT) adalah ketinggian air tanah yang diukur dari permukaan. Identifikasi muka air tanah dilakukan untuk mengestimasi kedalaman lapisan tanah yang jenuh air karena perilaku likuifaksi potensial terjadi pada tanah yang jenuh air. Tanah dengan kondisi jenuh air memiliki daya dukung yang relatif rendah daripada tanah dengan kondisi tak jenuh air. Disamping itu, kedalaman Muka Air Tanah diperluka untuk menghitung nilai tegangan total efektif $\tan a h\left(\sigma_{\mathrm{v}}{ }^{\prime}\right)$ dan untuk kebutuhan perhitungan lainnya (cyclic stress ratio).Dari data diperoleh kedalaman muka air tanah daerah ini $0,3 \mathrm{~m}$ di bawah permukaan tanah. 


\subsubsection{Magnitudo Gempa dan Percepatan Tanah Maksimum}

Magnitudo empa dan percepatan tanah maksimum digunakan dalam perhitungan cyclic stress ratio. Untuk penelitian ini menggunakan nilai magnitude dan percepatan tanah maksimum data gempa terdahulu. Parameter ini diperoleh dari data gempa Padang Pariaman pada tanggal 30 September 2009 yaitu magnitude 7,6 dan $a_{\max }$ sebesar $0,28 \mathrm{~g}$ berdasarkan gambar 3.3. Dalam perhitungan, percepatan tanah digunakan dalam satuan Gal.

$$
\begin{aligned}
a_{\max } & =0,28 \mathrm{~g} \times 100=280 \\
& =280 \times 9,8 \mathrm{~m} / \mathrm{s}^{2} \\
& =274,68 \mathrm{gal}
\end{aligned}
$$

\subsection{Perhitungan Potensi Likuifaksi CPT}

Contoh perhitungan : (Raden Saleh 1)

\section{Lapisan 1}

1. Data

Nomor Lapisan $\quad:$

Kedalaman lapisan $\quad: 100 \mathrm{~cm}$

GWL $: 30 \mathrm{~cm}$

$\mathrm{q}_{\mathrm{c}}$

$: 6 \mathrm{~kg} / \mathrm{cm}^{2}$

Berat volume tanah $(\gamma) \quad: 0,0019 \mathrm{~kg} / \mathrm{cm}^{3}$

Magnitudo (M) : 7,6 SR

Percepatan tanah maksimum $\quad: 247,68$ gal

Percepatan gravitasi $(\mathrm{g}) \quad: 980 \mathrm{~cm} / \mathrm{det}^{2}$

2. Tegangan Total $\left(\sigma_{0}\right)$

$$
\begin{aligned}
\sigma_{0} & =\gamma \times \mathrm{h} \\
& =0,0019 \times 100 \\
& =0,190 \mathrm{~kg} / \mathrm{cm}^{2}
\end{aligned}
$$

3. Tegangan efektif

$$
\begin{aligned}
\sigma_{0}{ }^{\prime} & =\sigma_{0}-\mathrm{u} \\
& =(\gamma \times \mathrm{h})-\left(\gamma_{\mathrm{w}} \times \mathrm{h}_{\mathrm{w}}\right) \\
& =(100 \times 0,0019)-(0,000981 \times(100-30)) \\
& =0,121 \mathrm{~kg} / \mathrm{cm}^{2}
\end{aligned}
$$

4. Normalisasi perlawanan konus $\left(\mathrm{q}_{\mathrm{c} 1}\right)$

$$
\begin{aligned}
\mathrm{q}_{\mathrm{c} 1} & =\mathrm{CN} \times \mathrm{q}_{\mathrm{c}} \\
& =1,6 \times 6 \\
& =9,6 \mathrm{~kg} / \mathrm{cm}^{2}
\end{aligned}
$$

5. Reduksi tegangan siklik $\left(\mathrm{r}_{\mathrm{d}}\right)$

$$
\begin{aligned}
r_{\mathrm{d}} & =\frac{1,0-0,4113 \mathrm{z}^{1,5}+0,04052 \mathrm{z}+0,001753 \mathrm{z}^{1,5}}{1,0-0,4177 \mathrm{z}^{0,5}+0,05729 \mathrm{z}-0,006205 \mathrm{z}^{1,5}+0,00121 \mathrm{z}^{2}} \\
\mathrm{r}_{\mathrm{d}} & =\frac{1,0-0,4113 \times 1^{1,5}+0,04052 \times 1+0,001753 \times 1^{15}}{1,0-0,4177 \times 1^{0,5}+0,05729 \times 1-0,006205 \times 1^{1,5}+0,00121 \times 1^{2}} \\
& =0,994
\end{aligned}
$$


6. Cyclic Stress Ratio

Seed \& Idriss

$$
\begin{aligned}
\operatorname{CSR} & =0,65 \times\left(\frac{a_{\max } \times \sigma_{0}}{g \times \sigma_{0}{ }^{\circ}}\right) \times \Gamma_{\mathrm{d}} \\
\operatorname{CSR} & =0,65 \times\left(\frac{274,67 \times 0,190}{980 \times 0,121}\right) \times 0,994 \\
& =0,284
\end{aligned}
$$

\section{Lapisan 2}

1. Data

Nomor Lapisan $\quad: 2$

Kedalaman lapisan $\quad: 200 \mathrm{~cm}$

GWL

$: 30 \mathrm{~cm}$

$\mathrm{q}_{\mathrm{c}}$

$: 22 \mathrm{~kg} / \mathrm{cm}^{2}$

Berat volume tanah $(\gamma)$

Magnitudo (M)

: $0,0019 \mathrm{~kg} / \mathrm{cm}^{3}$

Percepatan tanah maksimum $\quad: 247,68$ gal

Percepatan gravitasi (g) $\quad: 980 \mathrm{~cm} / \mathrm{det}^{2}$

2. Tegangan Total $\left(\sigma_{0}\right)$

$$
\begin{aligned}
\sigma_{0} & =\gamma \times h \\
& =200 \times 0,0019 \\
& =0,38 \mathrm{~kg} / \mathrm{cm}^{2}
\end{aligned}
$$

3. Tegangan efektif

$$
\begin{aligned}
\sigma_{0}{ }^{\prime} \quad & =\sigma_{0}-\mathrm{u} \\
& =(\gamma \times \mathrm{h})-\left(\gamma_{\mathrm{w}} \mathrm{x} \mathrm{h}_{\mathrm{w}}\right) \\
& =(200 \times 0,0019)-(0,000981 \times(200-30)) \\
& =0,213 \mathrm{~kg} / \mathrm{cm}^{2}
\end{aligned}
$$

4. Normalisasi perlawanan konus $\left(\mathrm{q}_{\mathrm{c} 1}\right)$

$$
\begin{aligned}
\mathrm{q}_{\mathrm{cl} 1} & =\mathrm{CN} \times \mathrm{q}_{\mathrm{c}} \\
& =1,6 \times 22 \\
& =35,2 \mathrm{~kg} / \mathrm{cm}^{2}
\end{aligned}
$$

5. Reduksi tegangan siklik $\left(\mathrm{r}_{\mathrm{d}}\right)$

$$
\begin{aligned}
r_{d} & =\frac{1,0-0,4113 z^{1,5}+0,04052 z+0,001753 z^{1,5}}{1,0-0,4177 z^{0,5}+0,05729 z-0,006205 z^{1,5}+0,00121 z^{2}} \\
r_{d} & =\frac{1,0-0,4113 \times 2^{1,5}+0,04052 \times 2+0,001753 \times 2^{1,5}}{1,0-0,4177 \times 2^{0,5}+0,05729 \times 2-0,006205 \times 2^{1,5}+0,00121 \times 2^{2}} \\
& =0,987
\end{aligned}
$$

6. Cyclic Stress Ratio

Seed \& Idriss

$$
\begin{aligned}
C S R & =0,65 \times\left(\frac{a_{\max } \times \sigma_{a}}{g \times \sigma_{o}^{\prime}}\right) \times r_{d} \\
C S R & =0,65 \times\left(\frac{274,67 \times 0,38}{980 \times 0,213}\right) \times 0,987 \\
& =0,321
\end{aligned}
$$

14 | JURNAL REKAYASA SIPIL 


\section{Lapisan 3}

1. Data

Nomor Lapisan $\quad: 3$

Kedalaman lapisan $\quad: 300 \mathrm{~cm}$

GWL $: 30 \mathrm{~cm}$

$\mathrm{q}_{\mathrm{c}} \quad: 32 \mathrm{~kg} / \mathrm{cm}^{2}$

Berat volume tanah $(\gamma) \quad: 0,0019 \mathrm{~kg} / \mathrm{cm}^{3}$

Magnitudo (M) : 7,6 SR

Percepatan tanah maksimum $\quad: 247,68$ gal

Percepatan gravitasi $(\mathrm{g}) \quad: 980 \mathrm{~cm} / \mathrm{det}^{2}$

2. Tegangan Total $\left(\sigma_{0}\right)$

$$
\begin{aligned}
\sigma_{0} & =\gamma \times h \\
& =300 \times 0,0019 \\
& =0,57 \mathrm{~kg} / \mathrm{cm}^{2}
\end{aligned}
$$

3. Tegangan efektif

$$
\begin{aligned}
\sigma_{0} \quad & =\sigma_{0}-\mathrm{u} \\
& =(\gamma \times \mathrm{h})-\left(\gamma_{\mathrm{w}} \times \mathrm{h}_{\mathrm{w}}\right) \\
& =(300 \times 0,0019)-(0,000981 \times(300-30)) \\
& =0,305 \mathrm{~kg} / \mathrm{cm}^{2}
\end{aligned}
$$

4. Normalisasi perlawanan konus $\left(\mathrm{q}_{\mathrm{c} 1}\right)$

$$
\begin{aligned}
\mathrm{q}_{\mathrm{cl}} \quad & =\mathrm{CN} \times \mathrm{q}_{\mathrm{c}} \\
& =1,6 \times 32 \\
& =51 \mathrm{~kg} / \mathrm{cm}^{2}
\end{aligned}
$$

5. Reduksi tegangan siklik $\left(\mathrm{r}_{\mathrm{d}}\right)$

$$
\begin{aligned}
r_{d} & =\frac{1,0-0,4113 z^{1,5}+0,04052 z+0,001753 z^{1,5}}{1,0-0,4177 z^{0,5}+0,05729 z-0,006205 z^{1,5}+0,00121 z^{2}} \\
r_{d} & =\frac{1,0-0,4113 \times 3^{1,5}+0,04052 \times 3+0,001753 \times 3^{1,5}}{1,0-0,4177 \times 3^{0,5}+0,05729 \times 3-0,006205 \times 3^{1,5}+0,00121 \times 3^{2}} \\
& =0,979
\end{aligned}
$$

6. Cyclic Stress Ratio

Seed \& Idriss

$$
\begin{aligned}
C S R & =0,65 \times\left(\frac{a_{\max } \times \sigma_{o}}{g \times \sigma_{o}^{\prime}}\right) \times r_{d} \\
C S R & =0,65 \times\left(\frac{274,67 \times 0,57}{980 \times 0,305}\right) \times 0,979 \\
& =0,333
\end{aligned}
$$

\section{Lapisan 4}

1. Data

Nomor Lapisan

$: 4$

Kedalaman lapisan

$: 400 \mathrm{~cm}$

GWL

$: 30 \mathrm{~cm}$

$\mathrm{q}_{\mathrm{c}}$

: $90 \mathrm{~kg} / \mathrm{cm}^{2}$

Berat volume tanah $(\gamma)$

Magnitudo (M)$$
\text { : } 0,0019 \mathrm{~kg} / \mathrm{cm}^{3}
$$$$
: 7,6 \mathrm{SR}
$$ 
Percepatan tanah maksimum Percepatan gravitasi (g)

: 247,68 gal : $980 \mathrm{~cm} / \mathrm{det}^{2}$

2. Tegangan Total $\left(\sigma_{0}\right)$

$$
\begin{aligned}
\sigma_{0} & =\gamma \times h \\
& =400 \times 0,0019 \\
& =0,722 \mathrm{~kg} / \mathrm{cm}^{2}
\end{aligned}
$$

3. Tegangan efektif

$$
\begin{aligned}
\sigma_{0}{ }^{\prime} \quad & =\sigma_{0}-\mathrm{u} \\
& =(\gamma \times \mathrm{h})-\left(\gamma_{\mathrm{w}} \mathrm{x} \mathrm{h}_{\mathrm{w}}\right) \\
& =(400 \mathrm{x} 0,0019)-(0,000981 \times(400-30)) \\
& =0,397 \mathrm{~kg} / \mathrm{cm}^{2}
\end{aligned}
$$

4. Normalisasi perlawanan konus $\left(\mathrm{q}_{\mathrm{c} 1}\right)$

$$
\begin{aligned}
\mathrm{q}_{\mathrm{c} 1} & =\mathrm{CN} \times \mathrm{q}_{\mathrm{c}} \\
& =1,6 \times 90 \\
& =144 \mathrm{~kg} / \mathrm{cm}
\end{aligned}
$$

5. Reduksi tegangan siklik $\left(r_{d}\right)$

$$
\begin{aligned}
r_{d} & =\frac{1,0-0,4113 z^{15}+0,04052 z+0,001753 z^{1,5}}{1,0-0,4177 z^{0,5}+0,05729 z-0,006205 z^{1,5}+0,00121 z^{2}} \\
r_{d} & =\frac{1,0-0,4113 \times 4^{1,5}+0,04052 \times 4+0,001753 \times 4^{1,5}}{1,0-0,4177 \times 4^{0,5}+0,05729 \times 4-0,006205 \times 4^{1,5}+0,00121 \times 4^{2}} \\
& =0,973
\end{aligned}
$$

6. Cyclic Stress Ratio

Seed \& Idriss

$$
\begin{aligned}
C S R & =0,65 \times\left(\frac{a_{\max } \times \sigma_{o}}{g \times \sigma_{o}^{\prime}}\right) \times r_{d} \\
C S R & =0,65 \times\left(\frac{274,67 \times 0,722}{980 \times 0,397}\right) \times 0,973 \\
& =0,339
\end{aligned}
$$

\subsection{Menentukan potensi likuifaksi berdasarkan hubungan CSR dan perlawanan Konus terkoreksi}

Setelah melakukan perhitungan, dilamjutkan dengan memasukkan data pada grafik seperti gambar 3.1. Pemilihan grafik didasari oleh data sekunder dari analisa butiran tanah di lokasi. Grafik tersebut merupakan hubungan antara CSR dan perlawanan konus terkoreksi $\left(\mathrm{q}_{\mathrm{c} 1}\right)$. Hubungan CSR dan $\mathrm{q}_{\mathrm{c} 1}$ terlihat seperti pada gambar 4.1. untuk daerah Raden Saleh 1, 2 dan 3

Dari gambar 4.1 dapat dilihat bahwa cyclic stress ratio (CSR) dan perlawanan konus terkoreksi dari tiap kedalaman menunjukan tanah berpotensi terjadinya likuifaksi. Hal ini ditujukkan dengan sebaran titik pada grafik di daerah potensi likuifaksi. Selanjutnya dengan perhitungan yang sama dengan diatas, dengan data-data masukan untuk daerah Siteba dapat dilihat pada gambar 4.2. 


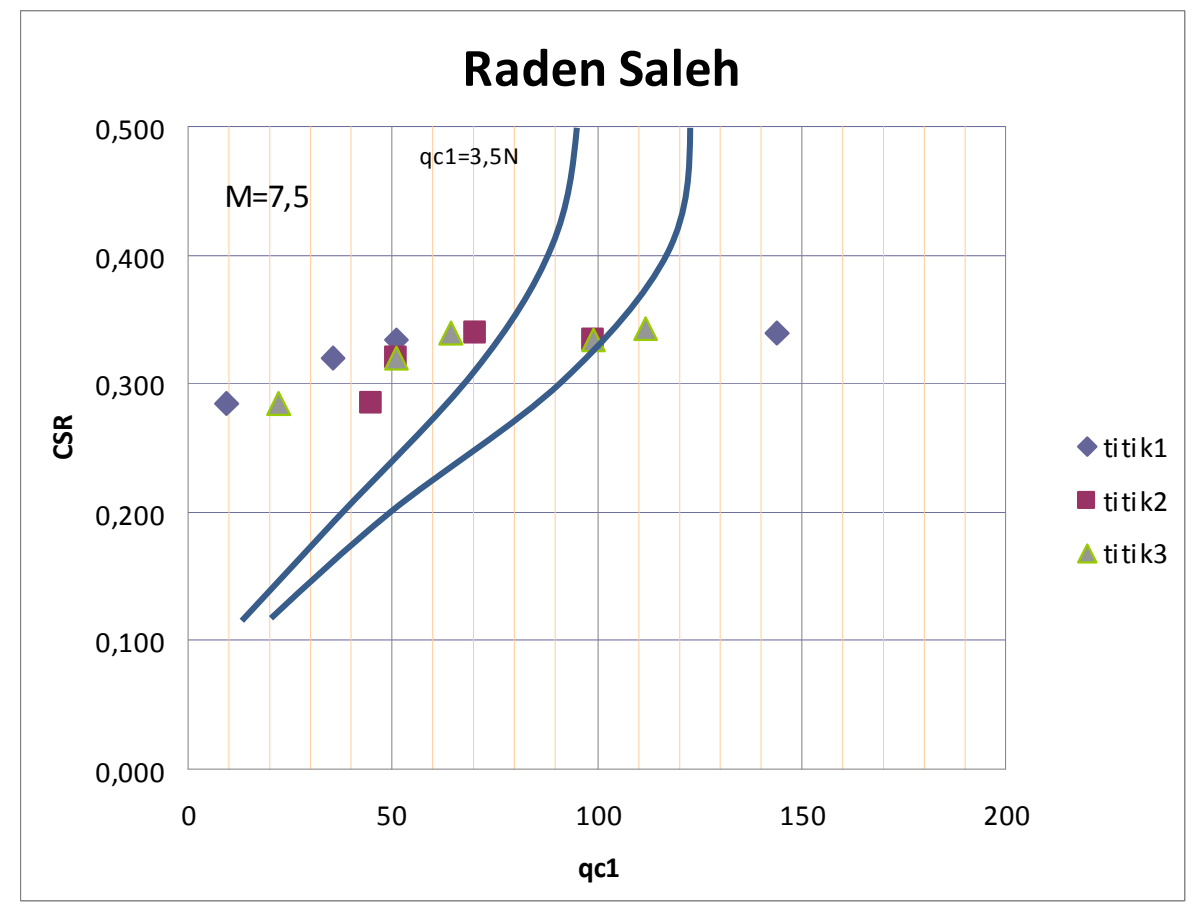

Gambar 4.1 Angka Keamanan vs Lapisan pada daerah Purus (Raden Saleh)

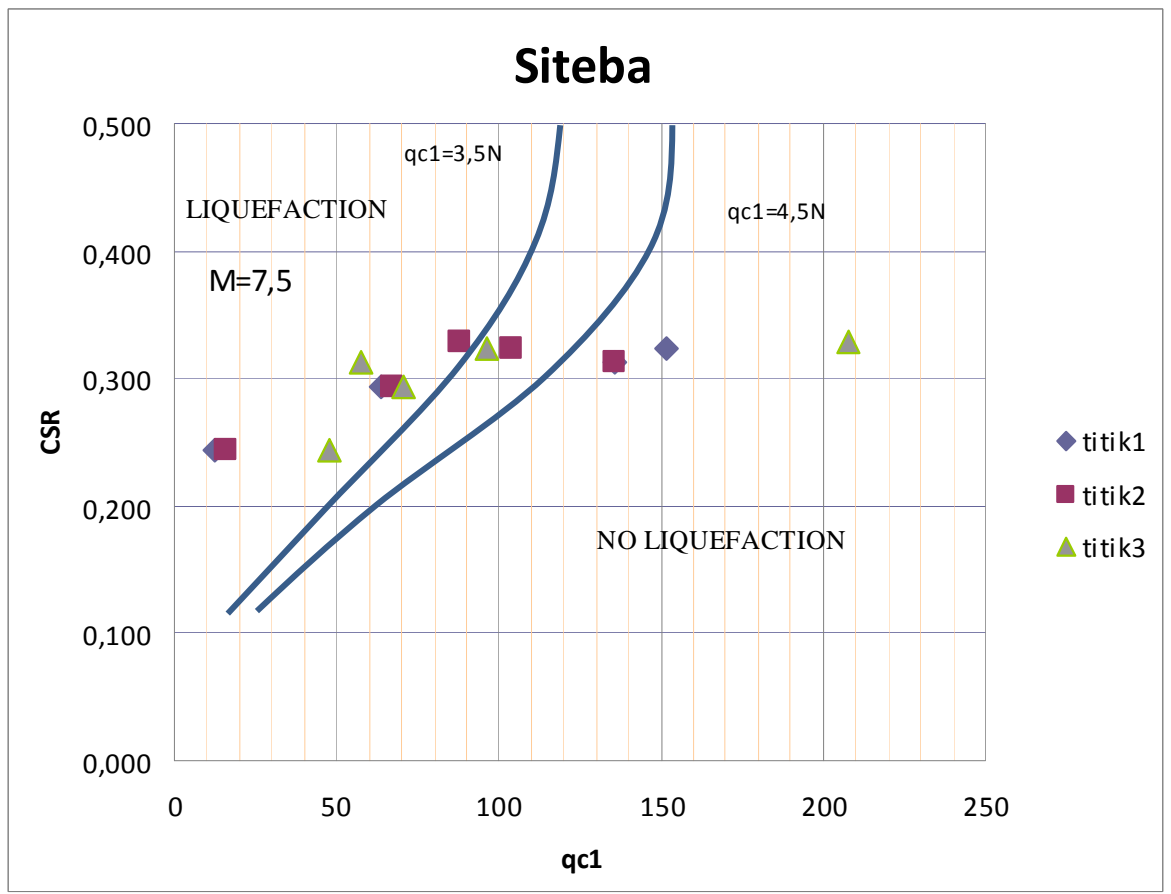

Gambar4.2 Angka Keamanan vs Lapisan pada daerah Siteba

Dari gambar 4.2 diatas dapat dilihat bahwa cyclic stress ratio (CSR) dan perlawanan konus terkoreksi dari tiap kedalaman menunjukan tanah berpotensi terjadinya likuifaksi, namun jika dibandingkan tidak sebanyak sebaran potensi likuifaksi Purus (Raden Saleh). Hal ini ditujukkan dengan sebaran titik pada grafik di daerah potensi likuifaksi gambar 4.2 Kemudian untuk daerah ke 3(tiga) yaitu By Pass, perhitungan yang sama dengan diatas, dengan data-data masukan untuk daerah Siteba dapat dilihat pada gambar 4.3 berikut ini. 


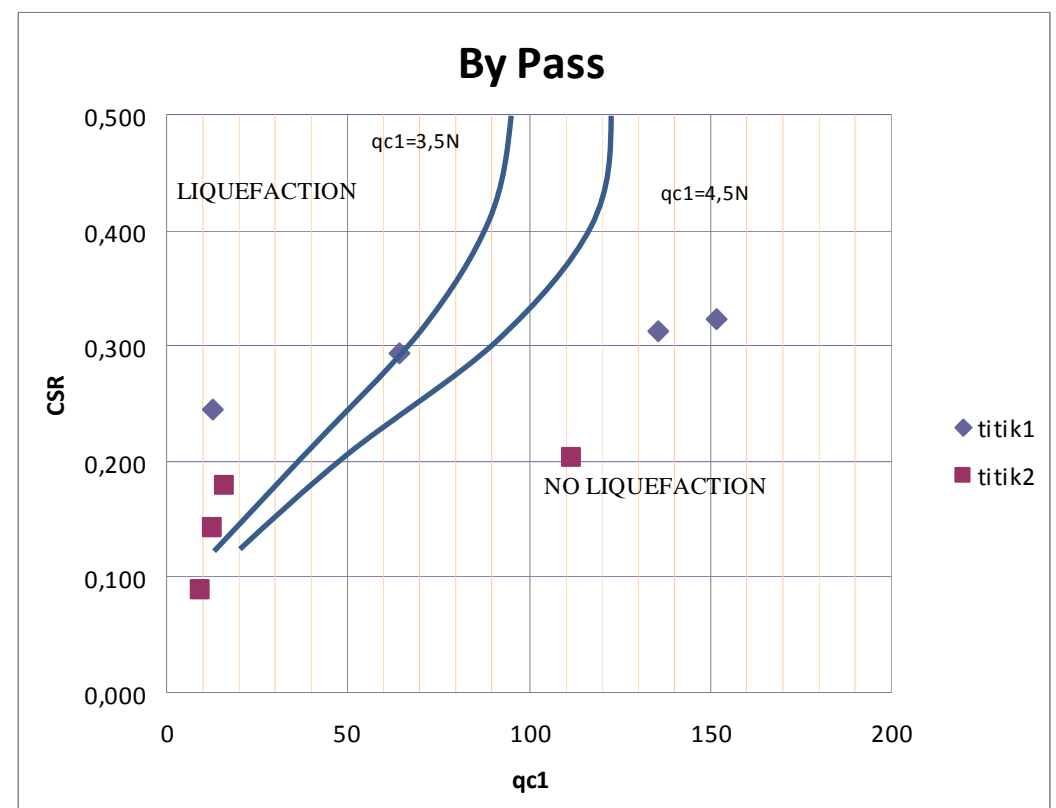

Gambar 4.3 Angka Keamanan vs Lapisan pada daerah By Pass

Selanjutnya dari gambar 4.3 diatas dapat dilihat bahwa cyclic stress ratio (CSR) dan perlawanan konus terkoreksi dari tiap kedalaman menunjukan tanah, lebih cenderung tidak berpotensi terjadinya likuifaksi, namun kalau dipengaruhi oleh muka air yang tinggi maka potensi likuifaksi akan terjadi, ini terlihat sebaran titik potensi likuifaksi pada grafik di daerah potensi likuifaksi gambar 4.3

\section{KESIMPULAN DAN SARAN}

\subsection{Kesimpulan}

Setelah dilakukan perhitungan dan analisis data hasil, maka dapat disimpulkan bahwa lapisan sedimen tanah di daerah Purus (Raden Saleh) dan Siteba, memiliki karakteristik sebagai berikut :

1. Dari hasil uji lapangan, maka daerah yang aman terhadap potensi likuifaksi diperkirakan lebih aman pada nilai konus qc $>100 \mathrm{~kg} / \mathrm{cm} 2$.

2. Tipikal jenis tanah untuk lokasi penyelidikan didominasi oleh jenis tanah lanau kepasiran dan pasir berlanau.

3. Untuk daerah Purus dan Siteba lebih berpotensi terjadi likuifaksi dan untuk daerah By Pass hanya bila dipengaruhi muka air yang tinggi, hal ini ditunjukan olah faktor keamanan yang kecil dari 1,5

4. Dari hasil kajian tentang potensi likuifaksi, untuk mitigasi bencana di kota Padang, maka perlu kebijakan pembangunan ke arah Timur kota dan sistem pondasi yang dibuat adalah pondasi dalam.

\subsection{Saran}

Berdasarkan dari hasil penelitian, maka dapat disarankan sebagai berikut :

1. Hasil perhitungan yang didapat sebaiknya dapat dibandingkan dengan metoda yang lain, misalnya dengan uji penetrasi standar (SPT) 
2. Titik penyelidikan tanah harus lebih banyak lagi, sehingga hasil yang diperoleh dapat lebih meyakinkan dalam hal potensi likuifaksi.

3. Untuk menyatakan peta likuifaksi yang dapat diterima oleh semua pihak untuk wilayah kota Padang, maka harus dilakukan penelitian untuk semua titik yang mewakili semua kecamatan di Padang.

\section{DAFTAR KEPUSTAKAAN}

Das, BM., (1983), Fundamental of Soil Dynamics, Elsevier Pub., NewYork

Hakam A dan Warman Hendri (2011), Penelusuran Likuifaksi Padang, Proceeding of 9th Indonesian Geotechnical Conference and 15th Annual Scientific Meeting, HATTI, Jakarta

Hakam A (2010), Padang Liquefaction Potential, Proceeding HATTI, Yogyakarta

Hakam A and Oscar F Nur (2007), Liquefaction analysis of silty sand deposit due to west Sumatra Earthquake on 6th March 2007, Proceeding of International Symposium on Disaster in Indonesia, Padang.

Hutapea B.M., Toha F.X.,Warman Hendri,Widiarso M., Idrus, Prakoso W.,Simatupang P., Sengara I.W., Irsyam M., Kertapati E., Rahardjo P.P., Pandita, Bambang W., Towhata I., Gratchev I., Mooney W., McGarr A., Rudianto S., Cabrera C., Henderson S., Woods K. dan Cedillos V., (2010), Sumatra September 30, 2009 Earthquake: Preliminary Geotechnical Assessment Report , Indonesian Society for Geotechnical Engineering-Bandung Institute of Technology-Center for Geological Resources Parahyangan Catholic University-Building Construction Advisory Board DKI Jakarta-University of Tokyo-United States Geological Survey-Earthquake Engineering Research Institute.

Gusti P, Hendri (2009),Analisa Potensi Likuifaksi Berdasarkan Data Pengujjian Sondir (Studi Kasus GOR Haji Agus Salim dan Lapai, Padang)

Seed, H. Bolton dan Idriss I.M., Ground Motion and Soil Liquefaction During Earthquake, Earthquake Engineering Research Institute, Berkeley, 1982.

Shibata, T. and Teparaksa, W. (1988), Evaluation of liquefaction potential of soils using cone penetration tests, Soils and Foundations, Japanese of Soil Mechanics and Foundation Engineering, Vol. 28., N0. 2, pp. $49-60$

Wikipedia (2009): http : // en.wikipedia.org / w / title =1964_Niigata_earthquake \& action 